\title{
Women Claim Islam
}

\author{
Miriam Cooke \\ New York: Routledge, 2001. 175 pages.
}

This book embarks on a sojoum into the stories and autobiographies of Arab women writers who "claim Islam" by "writing themselves into the history of the twentieth century." Being situated outside their nations' historical narratives, Cooke examines the literary practices of Arab Muslim women who have entered into global political discourses as vibrant public intellectuals, rather than as history's invisible subtext. According to her, Arab Muslim women "have been left out of history, out of the War Story, out of the narratives of emigration and exile, out of the physical and hermeneutical spaces of religion." Thus Muslim women intellectuals and writers are challenging the erasures of their experiences in the public and discursive spaces of nation, community, and faith.

Cooke argues that women have become the "symbolic center" in societies increasingly dominated by Islamic discourse. But while this discourse gives "unprecedented importance to women," it also centers them as pivotal to the "virtuous Muslim community" and thereby dictates constricting rules for their "appropriate behavior." This has resulted in a preoccupation with regulating and policing women's bodies (clearly evident in Talibanized Afghanistan). Yet at the same time, shifting women's experiences from the margins to the center of discursive focus has allowed their voices to emerge in new ways. In many cases, this stakes their claim to a more empowering Islamic identity. This movement has allowed Muslim women writers and intellectuals to develop a gendered Islamic epistemology. According to Cooke, these women "do not challenge the sacrality of the Qur'an, but they do examine the temporality of its interpretations." 
Cooke examines the stories of Muslim women who seek to claim their voices and redefine their identities in more politicized ways that represent a burgeoning Islamic feminist movement. In the introduction, she articulately and intelligently lays out the historical, theological, and political contexts for the development of Islamic feminism. Yet she concedes that feminism has been tainted by the often imperialist approach of the western feminist movement. Indigenous feminist epistemologies spearheaded by Muslim women often have used an alternative terminology, such as womanists or remakers of women. However, following the call of cultural critic Anne McClintock, Cooke argues that the historical resonance of feminism needs to be maintained, albeit in a more inclusive formulation, to subvert the hegemonic control that western white feminists have garnered over the nature of feminist discourse. Despite this, the author does not locate or question her own social position in relation to her research among Muslim women. This lack of critical self-reflexivity leaves open the question of whether she also may be complicit in maintaining dominant hegemonic control over Muslim women's discourses.

Cooke follows the trajectory of political and religious developments in the Arab world to examine Arab women's resistance to androcentric constructions of "official Islamic knowledge." In the early part of the twentieth century, such Arab feminists as Huda Shaarawi and Nazira Zayn al-Din openly challenged the male authority that has traditionally framed theological, cultural, and political discourses about Muslim women. These women provided an entry point into the political and scriptural debates regarding women's participation in the public domain and their role as interpreters of Islamic doctrine. From these nascent roots of Islamic feminist thought and critique, Cooke then situates more contemporary examples of women in the Arab world who operate as public intellectuals, lecturing to other women, and opening up new pathways for understanding Islamic knowledge from a gendered standpoint.

While many of these discourses are largely centered within an Islamic paradigm, they bring new challenges to traditional patriarchal interpretations. These emergent discourses also raise significant questions posed by Cooke, such as: "How can one be modern, global, and yet observant? Will Islamically inspired responses to globalization help or harm women? What role will Islam play in shaping ethical, modern citizens who are able to survive in, as well as to critique, a rapidly transforming world?"

In chapter 1, "Arab Women's Literary History," Cooke examines two particular narratives that have been significant in defining how Arab intel- 
lectuals articulate their experiences: the narratives of the "war story" and the related narratives of exile and migration. Cooke begins by mapping the trajectory of Arab women's entry point into literary circles from a few little known fiction writers in Cairo and Beirut during the late nineteenth century to a slow yet progressive development of more contemporary authors and social commentators. The chapter focuses primarily on the gendering of the "Gulf War story" through her documentation of women's stories in Iraq and Kuwait and the work of various Arab women writers during that period. These are stories of violence, terror, and repression as well as narratives of emigration and exile. This chapter clearly articulates how writing becomes a powerful and yet dangerous tool of resistance.

Chapter 2, "In Search of Mother Tongue," examines the mother tongue's role in both women's and men's constructions of identity. This chapter presents a comparative analysis of autobiographical texts of four North African writers from the colonial and postcolonial period: Assia Djebar, Abdelkebir Khatibi, Albert Memmi, and Jacques Derrida. Cooke argues that, "for colonized men, distance from the colonizer's language entails distance from power" and that indigenous languages were disdained due to an association with illiteracy. Yet, I would add, this is evidence of internalized oppression and attests to the difficult project of decolonizing the mind. Cooke points to Assia Djebar's writing as a counterpoint: Djebar sees her indigenous language connecting her through past generations to a Berber warrior princess. In this way, she transcends "the trauma of language as possession or tool of exclusion" and thereby reveals its "generative and creative power." This analysis provides a provocative discussion about the nature of language, power, history, and gender.

Chapter 3, "Reviewing Beginnings," and chapter 4, "A Muslim Sister," explores Islamic feminism through the work of Assia Djebar, Nawal El Sadaawi, Fatima Mernissi, and Zaynab Al-Ghazali. In situating the notion of Islamic feminism, Cooke rightly takes on the argument of Haideh Moghissi, who denies that feminism and Islam can ever be compatible due to her assertion that the Shari'ah is not based on the equality of human beings. Cooke points out the obvious flaw in her argument: One cannot confound Islam with Islamic fundamentalism. She argues that Islamic feminism is not a "coherent identity," but one that is "contextually determined" and "strategic." Cooke does not define Islamic feminism as an identity per $s e$, but rather as "an attitude and intention to seek justice and citizenship for Muslim women." She goes on to chronicle how prominent and often controversial Islamic feminist writers have engaged history and scripture to 
provide models and agendas for developing an alternative gendered Islamic epistemology.

Many may contest the positioning of Djebar, El Sadaawi, and Mernissi as "Islamic feminists" (including perhaps these women themselves), yet Cooke demonstrates how they each engage in a feminist critique of a patriarchal social order seen as inconsistent with Islam's ethos. Also included in the broad category is Zaynab Al-Ghazali, an Egyptian Islamist who, while holding conservative views on women's role, lived a politically active life in the pursuit of jihad through da'wah and social advocacy. By positioning each woman in the space of Islamic feminist action and critique, Cooke creates a broad framework for Islamic feminism that powerfully speaks to the need for diverse Muslim women to develop transnational alliances and find common ground based on a quest for social justice and women's equality in the social, economic, and political spheres.

In Chapter 5, "Multiple Critique," Cooke links Islamic feminism with postcolonial feminism and examines the multiples spaces of identity and social and political critiques that Islamic feminists must take up both locally and globally. This links the multiple and interconnected oppressions faced by Muslim women, such as challenging sexism within one's community and battling racism outside. Cooke then discusses work of various contemporary Muslim women's organizations and NGOs and urges increased networking and coalition-building within a broad transnational feminist framework.

Chapter 6, "Changing the Subject," explores the politics of identity, representation, and discursive authority in the academic world of Middle Eastern and Muslim women's studies. The chapter begins by focusing on the impact of the Intifada and the Gulf War on the self-perception and identity development of Arab-American women scholars. Cooke then examines debates within the politics of knowledge production relating to Arab women and resistance to the discursive authority of white American feminists.

Overall, Cooke provides a critical, provocative, analytically penetrating, and, perhaps for some, controversial reading of "women claiming Islam" in historical and contemporary writings. A very well written account, it sets an important standard in the field of Muslim women's studies. 